\title{
New and little known species of fungus gnats (Diptera: Mycetophilidae) from Kunashir Island
}

\author{
Новые и малоизвестные виды грибных комаров \\ (Diptera: Mycetophilidae) с о. Кунашир
}

\begin{abstract}
A.I Zaitzev
А.И. Зайџев

Moscow City Pedagogical University, Institute of Mathematics, Informatics and Natural Sciences, Department of Biology, Ecology and Methodics of Biological Education, Chechulina str. 1, Moscow 111568, Russia. E-mail: azaitzev@mail.ru

Московский городской педагогический университет, Институт математики, информатики и естественных наук, кафедра биологии, экологии и методики обучения биологии, ул. Чечулина 1, Москва 111568, Россия.
\end{abstract}

KEYWORDS: Diptera, Mycetophilidae, Acnemia, Boletina, Russia, Kunashir, taxonomy, description, new species.

КЛЮЧЕВЫЕ СЛОВА: Diptera, Mусеtophilidae, Acnemia, Boletina, Россия, Кунашир, таксономия, описание, новый вид.

ABSTRACT. Two new species of fungus gnats Acnemia sundukovi and Boletina sublagena spp.n. described from Kunashir Island (South Kuril Isles). New data on distribution of Acnemia kurilensis Zaitzev, 2001 given and illustrations of male terminalia provided.

РЕЗЮМЕ. Приводятся описания двух новых видов грибных комаров - Acnemia sundukovi и Boletina sublagena spp.n. с о. Кунашир с иллюстрациями терминалий самцов, а также новые данные о распространении Acnemia kurilensis Zaitzev, 2001.

\section{Introduction}

Major data on sciaroid flies from Kunashir island provided in papers by A. Zaitzev [Zaitzev, 1994, 2003]. Before these papers were published, only a few species were checked in this island [Okada, 1937]. For the present, there are about 130 species registered.

During the revision of the material from Kunashir I. collected by Dr. Yu. Sundukov in 2013-2014, two new species were found. Their description is given below.

\section{Material and methods}

The material was collected in Malaise trap. Male terminalia were detached and heated in $10 \% \mathrm{KOH}$ solution, neutralized by a solution of acetic acid, washed in water and than stored in glycerine. The morphological terms used here mainly follow Søli [1997]. Type material is deposited in the Zoological Museum of Moscow State University (ZMUM).

\section{Acnemia sundukovi Zaitzev sp.n.}

Figs 1-3.

MATERIAL EXAMINED. Holotype $\sigma^{7}$, RUSSIA: Kuril Is., SW Kunashir, Ivanovsky Cape, 21-28.IX.2013, Malaise trap, Yu. Sundukov leg. Paratypes: $3 \bigcirc^{7} \sigma^{7}$, same as holotype, 28-30.IX.2013 (ZMUM)

DESCRIPTION. Male. Head dark brown. Clypeus brown, two basal palpal segments light brown, remainder yellow. Antenna dark brown with yellow scspe, pedicel and basal part of first flagellomere. Sixth flagellomere about 2 times as long as wide.

Thorax brown. Mesonotum with yellow humeral spots. Pleurae brown. Anepimeron yellowish brown. Laterotergite with setae brown. Mediotergite with bristles, brown with yellow anterolateral parts.

Wings slightly infuscated brownish in apical part. Wing length 4.1-4.2 mm. Membrane with macrotrichia. Veins brown. Sc ending in $\mathrm{C}$ slightly beyound of $\mathrm{R}$; $\mathrm{rm}$ crossvein 2 times longer than $R_{s}$; stem of fork of $M_{1}$ and $M_{2}$ as long as $\mathrm{rm}$

Legs yellow. Trochanters dark brown. Fore tibia subequal in length to first tarsomere. Tarsi darkened. Mid tibia with $7 \mathrm{ad}, 7 \mathrm{~d}, 6 \mathrm{pd}$; hind tibia with $10 \mathrm{ad}, 11 \mathrm{~d}, 9 \mathrm{pd}$.

Abdomen brown, terminalia dark brown.

Female. Unknown.

BIOLOGY. Unknown.

ETYMOLOGY. New species is named in honour of Dr. Y. Sundukov (Lazo, Russia) who collected this material.

DIAGNOSIS. A. sundukovi sp.n. belongs to the longipes-group [Zaitzev, 1982]. It is close related to A. spathulata Zaitzev [Zaitzev, 2001], but distinctly differs by the straight apex of aedeagus and the lack of acute appendage on gonostyle.

Acnemia kurilensis Zaitzev, 2001

MATERIAL EXAMINED. $2 \sigma^{7} \sigma^{7}$, Russia: Kuril Is., SW Kunashir, Ivanovsky Cape, 21-22.X.2012, Malaise trap, Yu. Sundukov leg. (ZMUM). 

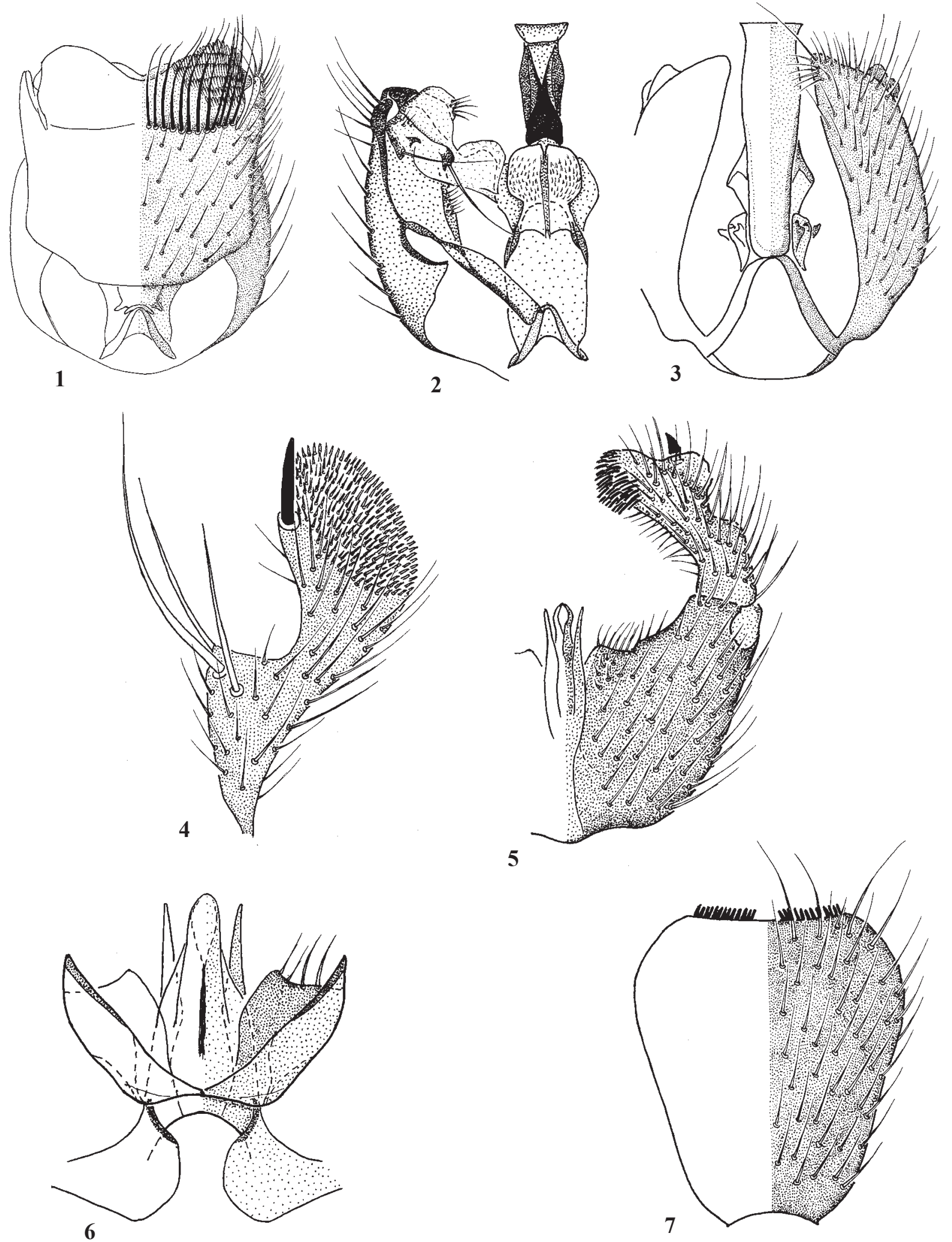

5

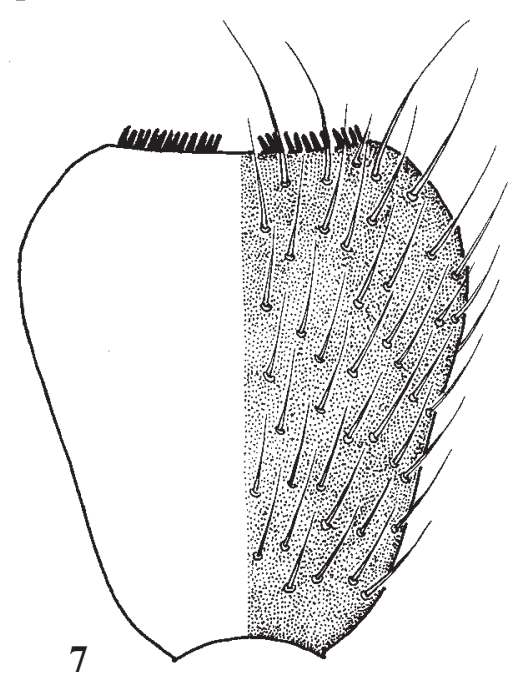

Figs 1-7. Males terminalia: 1-3 - Acnemia sundukovi sp.n.; 4-7 - Boletina sublagena sp.n.; 1 - dorsal view; 2 - dorsal view without tergite IX; 3, 5- ventral view; 4 - gonostyle; 6 - aedeagus; 7 - tergite IX.

Рис. 1-7. Терминалии самцов: 1-3 - Acnemia sundukovi sp.n.; 4-7 - Boletina sublagena sp.n.; 1 - сверху; 2 - сверху, тергит IX удален; 3,5 - снизу; 4 - гоностиль; 6 - эдеагус; 7 - тергит IX. 
This species was described by two males from Ushishir Island (Kuril Is.) [Zaitzev, 2001]. Differs from other species of the genus in the darkened apical parts of wings, in the shape of tergite IX (with narrow apical appendage) and in structure of gonocoxites (with two broad apical lobes).

\section{Boletina sublagena Zaitzev sp.n.}

Figs 4-7.

MATERIAL EXAMINED. Holotype $\sigma^{7}$, RUSSIA: Kuril Is., SW Kunashir, Ivanovsky Cape, 21-28.IX.2013, Malaise trap, Y. Sundukov leg. (ZMUM).

DESCRIPTION. Male. Head dark brown. Clypeus yellowish brown, mouthparts and palps yellow. Antennae dark brown with yellow scapus and pedicel. Sixth flagellomere abut 4 times as long as wide.

Mesonotum dark brown with yellow humeral spots. Antepronotum and preepisternum yellow. Anepisternum, anepimeron, laterotergite, mediotergite and scutellum dark brown. Laterotergite bare. Coxae, femora and tibiae yellow; trochanters darkened. Femora 2 with bases darkened ventrally,

\section{Boletina lagena}

Mesonotum with yellow T-shaped marking.

Lateral thoracal sclerites yellow.

Abdominal tergites II, III with yellow triangle spots on posterolateral corners. Tergite V dark brown.

Legs yellow.

Forking point of $\mathrm{Cu}$ situated slightly before the base of stem $\mathrm{M}$ fork.

Gonostylus with 2 claw-like spines on tip. femora 3 with brown apical parts and bases darkened ventrally. Tarsi darkened. Ratio of tibia to first tarsomere for front, mid and hind legs: 1.4, 1.3, 1.6. Fore tibia with 5 ad, 2 d, 2 pd, $3 \mathrm{p}$; mid tibia with 3 a, 4 d, $6 \mathrm{p}, 3 \mathrm{v}$; hind tibia with $5 \mathrm{ad}, 8 \mathrm{~d}$.

Wing length $4.2 \mathrm{~mm}$. Wings hyaline with slightly darkened apical part. Costa extending beyond tip of $R_{5}$ to $1 / 5$ of the distance between $R_{5}$ and $M_{1}$. Sc bare, ending before $R_{s}$. $\mathrm{Sc}_{2}$ situated at middle of cell R. Stem of median fork 3 times as long as ta. Forking point of $\mathrm{Cu}$ situated slightly beyond the base of stem $\mathrm{M}$ fork.

Abdomen dark brown. Tergites II-IV with yellow triangle spots on posterolateral corners. Terminalia brownish black. Gonostylus with strong spine near apex.

Female. Unknown.

BIOLOGY. Unknown.

ETYMOLOGY. The species' name indicates new species resemblance to B. lagena Sasakawa et Kimura.

DIAGNOSIS. The new species most closely resembles $B$. lagena [Sasakawa, Kimura, 1974]. It differs in following characters:

\section{Boletina sublagena}

Mesonotum with yellow humeral spots.

Anepisternum brown.

Abdominal tergites II-IV with yellow triangle spots on posterolateral corners. Tergite $\mathrm{V}$ with yellow triangle spot on anterolateral corners.

Femora 2, 3 with bases darkened ventrally. Femora 3 with brown apical parts.

Forking point of $\mathrm{Cu}$ situated slightly beyond the base of stem $\mathrm{M}$ fork.

Gonostylus without 2 claw-like spines on tip.
ACKNOWLEDGEMENTS. I thank Dr. Y. Sundukov (Lazo, Russia) for providing me with the Mycetophilidae material from Kunashir.

\section{References}

Okada I. 1937. Nachtrag zu den Nematoceren von den Kurilen (Diptera) // Trans. Sapporo Nat. Hist. Soc. Vol.15. Pt.1. P.3339.

Sasakawa M., Kimura T. 1974. Japanese Mycetophilidae (Diptera) VII. Genus Boletina Staeger // Scientific Reports Kioto Prefectural University, Agriculture. No.26. P.44-66.
Søli G.E.E. 1997. The adult morphology of Mycetophilidae (s.str.), with a tentative phylogeny of the family (Diptera, Sciaroidea) // Ent. Scand. Suppl.50. P.1-55.

Zaitzev A.I. 1982. [Dipterans of the genus Acnemia Winn. (Mycetophilidae) of the Holarctic fauna. 1] // Zoologichesky zhurnal. Vol.61. No.5. P.707-715 [in Russian].

Zaitzev A.I. 1994. Fungus gnats of the fauna of Russia and adjacent regions. Part I. Moscow: Nauka. 288 pp.

Zaitzev A.I. 2001. New species of fungus gnats from Russia and Italy (Diptera: Mycetophilidae) // Zoosyst. Rossica. Vol.9. No.2. P.453-458

Zaitzev A.I. 2003. Fungus gnats (Diptera, Sciaroidea) of the fauna of Russia and adjacent regions. Part II // Int. J. Dipterol. Res. Vol.14. Nos2-4. P.77-386. 